\title{
The Linkage between the U.S. Commercial Media System and the Crisis of the Korean Media Industry
}

\author{
Doobo Shim \\ Department of Media and Communications \\ Sungshin Women's University, Dongseon-dong, Seongbuk-gu, Seoul, Korea
}

\begin{abstract}
Reports on the Korean culture's gaining popularity among foreign audiences have filled the Korean news media for more than a decade by now. On the other hand, some observers have begun to argue that the hyper-commercialism has brought the Korean cultural industries to a crisis. By examining a brief history of U.S. commercial media system's global spread, this paper makes an effort to understand the Korean media industry within an international and historical framework. Secondly, it analyzes the processes of Korean media industry losing its competitiveness following the Korean Wave success. Based on the research findings, this paper warns against the potentially detrimental effects of commercial media system.
\end{abstract}

Keywords: commercialization, globalization, Korean Wave, media industry, popular culture

\section{INTRODUCTION}

Research on the international cultural content flow has long been occupied with "center vs. periphery" dichotomy. In other words, the U.S. as "the center" has been understood to dominate the global flow of information and content. Therefore, many communication scholars and policy-makers around the world have explored ways to inhibit the U.S. and Western cultural influences in their countries. One of such efforts was an international alliance against the U.S. and Western media power under the name of the New World Information and Communication Order (NWICO) in the 1970s. Forming the majority voice in meetings organized by the United Nations Educational, Scientific, and Cultural Organization (UNESCO) and the United Nations (UN), the Third World countries on the whole criticized the imbalanced international flow of information and content, signing declarations which would argue that the U.S. media imperialism undermined their national sovereignty.

For example, the Fourth Conference of Heads of State or Government of the Non-Aligned Countries was held in Algiers, Algeria, in September 1973, with 75 member states' attendance. It adopted a declaration that reads: "It is an established fact that the activities of imperialism are not confined solely to the political and economic fields but also cover the cultural and social fields, thus imposing an alien ideological domination over the peoples of the developing world" [1]. The declaration further demanded member nations' concerted action in the mass communication sector. At the $20^{\text {th }}$ session of the General

\footnotetext{
* Corresponding author.E-mail : doobo@sungshin.ac.kr Manuscript received Feb. 01, 2010 ; accepted Jun. 18, 2010
}

Conference of UNESCO (held in Paris, France, in 1978), the "Declaration on Fundamental Principles Concerning the Contribution of the Mass Media to Strengthening Peace and International Understanding, to the Promotion of Human Rights and to Countering Racialism, Apartheid and Incitement to War" was unanimously approved by 146 member states in attendance [2]. It was composed of recommendations to make global media representation and information flow more equitable and fairer.

Such diplomatic movements, however, did not work properly. The U.S. media industry charged that the UNESCO had become the headquarters for controlling the media. In its editorial, the New York Times (1978, November 27) called the 1978 UNESCO Declaration noted above as "a dangerous international declaration" which would repress the free press of the United States [3]. After the 1980 UNESCO General Conference (held in Belgrade, Yugoslavia) which passed a resolution demanding each member state to take all necessary steps to make their citizens well aware of the aforesaid Declaration, Sarah G. Power, Deputy Assistant Secretary of State for Human Rights and Social Affairs, stated firmly the U.S. intention not to accept the moves to curb "free flow of information" [2]. In December 1983, the U.S. Secretary of State George Shultz announced that the U.S.A. would withdraw from the UNESCO. He claimed that the UNESCO had drifted away from the original principles of its constitution and had been politicized. In order to weaken the campaign, the U.S. government and transnational media conglomerates pressured Third World countries out of the campaign by threatening to

This work was supported by the Sungshin Women's University Research Grant of 2008. 
cancel political and economic aids. The continuing development of new media and communication technologies has also been believed to portend a more solid dominance of the U.S. commercial media system [4].

A fear of the U.S. hegemonic order in international communication was, however, diminished with the discovery of "audience power" in communication process. For one, Joseph Straubhaar and others presented research on Latin American audiences preferring telenovela, a Latin American television drama ('drama' hereafter) genre, to U.S. imported dramas [5]. In much research of similar kind, audiences' subjectivities based on similar culture, language, and historical background were found to be important factors in their preference of media programs. For example, South Asian diasporas around the world actively consume Bollywood films; Hong Kong films commanded the whopping popularity among audiences across Asia. Case studies which investigated activities of regional media giants including TV Globo in Brazil, Phoenix Television in Hong Kong, Zee TV in India, Al-Jazeera in Qatar have subjected the theory of "one-way, top-down flow" international communication to revision [6].

Against the backdrop of this revisionist research on the international content flow, Korean media's popularity in Asia and beyond drew academic attention in the 2000s. The overseas fever of Korean drama, in particular, beginning in the late 1990s led to the coinage of "Korean Wave" or "Hallyu." It is now often cited as an important example of an East Asian popular culture co-existing with the dominant U.S. content [7]. This success of the Korean media industry spurred other Asian countries to develop their own media industries to export capacity. For example, both Japanese and Taiwanese government stressed the need to develop cultural industries spurred by the Korean case [8], [9]. On the other hand, Korean Wave also incurred xenophobic reactions in some countries.

While much of the research have investigated the Korean Wave's impact on audiences and media industries across Asia, I would rather examine the phenomenon's rebounding impact back on the Korean media industries. Did the commercial achievement overseas cause any changes in the Korean media industries? As such, this paper will examine the structural changes in the Korean media industry with close reference to the development of Korean Wave.

Proceeding with this analysis, I first provide a brief overview of the history of U.S. commercial media system's global spread within a previously noted "center vs. periphery" paradigm. Through this, we shall understand the Korean media industry within an international and historical framework. Second, I present an analysis of the processes of Korean media industry losing its competitiveness and accumulating some detrimental aspects following the Korean Wave success. And finally, I discuss and summarize some important points made in the paper.

\section{U.S. COMMERCIAL MEDIA SYSTEM AND THE GLOBAL CONTENT MARKET}

Critical social scientists around the world have expressed concerns about the U.S. media model. They argue that commercial media companies that maintain the U.S. model are more responsible to shareholders and advertisers than to their "public" mission. Therefore, the commercial media system leads to ordinary people's limited understanding of and participation in public affairs. As such, critical scholars argue that the commercial system is detrimental to democracy [10], [11].

This antipathy to corporate media system is also based on the traditional concept of culture. As Raymond Williams explained in his book Culture and Society: 1780-1950, culture is understood to be a domain separate from material production and economic activity, and market forces are thought to spoil culture's universal value of life enhancement [12]. Against this backdrop, the state assigned special status to "creative artists" who were regarded as a source of unfathomable inspiration and talent. When a large enough audience was not found for their work, the market was to blame and a state subsidy to the artists was justified [10]. In this regard, most countries in the world have considered broadcasting and film as vehicles for national culture, maintaining public broadcasting systems, protecting and financing them with government grants or license fees, different from the U.S. commercial model of broadcasting.

Cultural activity has developed into an industrial concern since the late 19th century, producing and distributing symbols in the form of goods and services within the capitalist mode. Cultural industries that generally include production and distribution of newspapers, magazines, films, records, and broadcasting flourished particularly in the U.S.A. as private businesses. This U.S. characteristic of the private media ownership is an outcome of the U.S. faith that non-state ownership (even if it may lead to a monopolistic situation) is a foundation of democracy. Americans strongly believed that private ownership of the mass media would guarantee pluralism or a diversity of views, standing in opposition to state- or public-ownership of the media.

Funded by Wall Street investors, by 1923 most major Hollywood studios established a vertical integration, linking production, distribution, and exhibition, gaining lower transaction costs, lower uncertainty of business, synchronization of supply and demand along the chain of products, and better publicity [13]. This combined ownership in the media industry came to an end by Hollywood Antitrust Case of 1948 but, deregulation began during the Reagan Administration in the 1980s, leading to a series of mergers and acquisitions in Hollywood. Now, all Hollywood majors are part of transnational media conglomerates, enjoying predominant positions in the global media market [11].

Although the laws require every U.S. broadcaster to air public affairs programs, all of major broadcasting companies such as $\mathrm{ABC}, \mathrm{NBC}$, and $\mathrm{CBS}$ are basically private, commercial entities. According to Robert McChesney, when the proposal of the Wagner-Hatfield Amendment to the Communications Act of 1934 was failed, that would have given $25 \%$ of all broadcasting facilities to educational and non-profit organizations and institutions, the idea of public-service broadcasting virtually perished in the U.S. society [4]. In 1970 the Public Broadcasting Service (PBS) was launched to provide more diversity in programming. Because of the aforementioned American doubts about public- or state-owned broadcasting, 
state and federal sources account for less than $50 \%$ of its funding. Therefore, PBS stations rely on corporate sponsorships and viewer contributions. As of the mid-1990s, while the federal spending on public broadcasting was only about \$260 million a year, corporate expenditure on broadcasting advertisement was estimated at \$36 billion [11]. The fact that most of the U.S. media companies have been developed as private, commercial organizations, which have merit in making swift response to audience tastes and trends, gave them a competitive advantage over public- or state-owned media corporations in the rest of the world, which were operating without competition in their home markets. Eventually, the global dominance of American popular culture engendered international resistances like NWICO as noted before.

Against the backdrop of the "triumph of neoliberalism" in the 1980s onwards, public broadcasting systems around the world have got commercialized or privatized. The unprecedented pace of new media development and the hopeful discourse of "Information Society" led many countries to rush to promote the media sector. For example, in the 1980s France and U.K. began to take new approaches to their cultural policies, realizing the cultural sector's growing economic contribution. In the early 1980s, the French government set up an investment fund for its national cultural industries, both to protect domestic industries against the U.S. cultural invasion, and to strengthen their export capacity. About the same time, the U.K. government's Information Technology Advisory Panel stressed the need for expanded government support to culture and mass media content on the similar account of the French initiative [10]. In this regard, the BBC began to commercialize its programs and other properties from the early 1990s through its subsidiary BBC Worldwide. Against the backdrop of European media commercialization, European film, broadcasting, and advertising industries aggressively hired the people from Hollywood. A European media company executive was reported to say "Americans know how to capture and hold an audience," by the Los Angeles Times [14].

When Korea began to go through democratization processes in 1987, after almost 30 years of dictatorial rules, mass media sector was not an exception. Instead of sticking to having only two television networks, both of which were public broadcasting systems, Seoul allowed a private broadcasting company to launch in 1991. It was to provide diversity in information and entertainment to the stifling Korean society, taking a cue from the U.S. media ideals. In addition, Korean cultural industries also began to chant the mantra "Learn from Hollywood" in order to develop competitiveness of Korean popular culture in markets at home and abroad [7].

Most national media systems are now incorporated into a tiered global, commercial media market. In this market, less than ten transnational media conglomerates comprise the first tier. They are Time Warner, Disney, News Corp., Bertelsmann, CBS Corporation, Viacom and NBC Universal. About six or seven dozen media concerns, which are largely regional powerhouses including Brazil's TV Globo and India's Zee TV, make up the second tier. Finally, thousands of local companies compose the third tier of the global media market [11]. In this global network, world's largest transnational media organizations and local and regional players work hand in hand. The local partners deliver global giants' customized content to audiences, while actively appropriating products and formats of the giants.

This global media market likewise facilitated Korean media exports. In the 1990s, many Asian countries introduced more commercial television channels, which led to a spurt of foreign program imports. In particular, the financial crisis that hit hard Asia in the late 1990s steered Asian media companies to "discover" cheaper Korean programs. In the end, Asian fans' consumption of Korean cultural productions, including television dramas, films and pop music, became a huge phenomenon called the Korean Wave.

These days, however, the Korean media industries seem to have some difficulties regarding their operations. In November 2008, Korean Association of Television Drama Productions expressed a concern that the future of Korean television drama is perilous. What happened to the Korean media industry which had been applauded as a prominent example of "from rags to riches" story in terms of cultural content production? I consider this a side-effect of the Korean Wave success on the Korean media industries. In the next, we shall examine the changes in the Korean television industry with a close reference to their relationship with the Korean Wave phenomenon.

\section{KOREAN WAVE'S ADVERSE EFFECT ON THE KOREAN MEDIA INDUSTRY}

In 2000, the combined salaries of two leading roles in a television drama episode were 3.6 million won, occupying about $10 \%$ of the whole production cost (36.5 million won). In 2008 , the combined salaries of two leading roles rose to between 40 million won and 60 million won on average, occupying about $40 \%$ of the whole production cost (between 100 million won and 150 million won) [15]. What caused these changes? The overseas success of Dae Jang Geum was a factor which propelled the average salaries for Korean leading actors and actresses. When Lee Young Ae, already a popular actress, made a contract to star in Dae Jang Geum, she received 6 million won per episode. However, after Dae Jang Geum experienced extensive success across Asia, promoting the Korean Wave fever that already gripped Asia in the early 2000s, the salaries for leading roles in Korean dramas skyrocketed. Actress Jeon Do-yeon made 15 million won per episode in her role in Lovers in Prague in 2005; actress Ko Hyeon-jeong earned 25 million won per episode in What's Up Fox? As of 2006; actor Kwon Sang-woo's per episode salary in Bad Love was 50 million won in 2007. It is reported that actor Song Seung-heon earned 70 million won per episode in East of Eden in 2008 .

In the 2000s, a new phenomenon appeared in Korea. Japanese or other Asian middle-aged women openly stalking their Korean idols with good cheer, including their filming location sites, real-life residences, and even wedding ceremonies (the case in point is the actor Kwon Sang-Woo's wedding in September 2008). The Korean media label these celebrities as "Hallyu stars" distinguished from other artistes who are not known to foreign fans. Television drama producers 
are eager to cast them in their projects with an expectation that Hallyu stars would bring more audiences, and in turn the stars demand excessive salaries.

The famous actor Bae Yong Joon received even more salaries than the actors noted above. In The Story of the First King's Four Gods, ${ }^{1}$ he made 250 million won per episode, which translated into a fact that he earned 6 billion won to star in the series. It is even reported that Bae would earn 150 million won per episode in the Godly Wine Drops of which filming is to start in late $2010[16]^{2}$ Considering that top-level actors in Korea are paid around 20-25 million won on average as of 2008, Bae received very expensive "Korean Wave premium." In this bubble period, every party concerned with the drama production demanded higher salaries. For example, some drama writers were reported to receive 20 million won per episode, and supporting actors' salaries also increased too much [18].

Because leading actors and actresses take too big pieces in the production cost pie, it is hard for producers to manage expenses. The only option for them is to save money on other aspects of production. For example, a producer of a historical drama hired only 100 actors for soldier roles for a "war" scene, making the scene look sloppy [19]. It is reported that some supporting actors in Bae Yong Joon-starring The Story of the First King's Four Gods had not received their salaries by December 2008, 12 months after the drama series signed off in Korea. What they heard was that their salaries would be paid when the production studio recovered the investment from foreign market sales. In November 2008, Korea Television Drama Directors Association made an outcry, maintaining that Korean television drama industry should go back to the days before the Korean Wave distorted the market [20]. It also decided that it would enforce a salary cap of 15 million won per episode on any actor and actress so that the current portion of actor salaries in the whole production cost should be lowered from $60 \%$ to $40-50 \%$ [21].

From a remote perspective, the problem of skyrocketing star salaries stems from the media reform processes beginning in 1987 as noted before. In order to promote television programming diversity, in 1991 the government imposed the "compulsory television programming outsourcing system" on terrestrial broadcasting channels, by which a certain percentage of broadcasting hours should be filled by independent production companies' programming [22]. Thereafter, the percentage of outsourced programming on networks had been increased, finally reaching about $40 \%$ on KBS, $35 \%$ on MBC and SBS, and $20 \%$ on EBS as of 2008 .

However, as the networks are in a position to choose among program proposals from many independent productions, the indies keenly compete to cast "Hallyu stars" in order to add value to their programs. The "illusion" of success brought about

\footnotetext{
1 An English reading of the original Korean title is "Tae Wang Sa Shin Gi,” with Hanja or Chinese character “太王四神記.” It is also translated into English as The Legend.

2 In January 2010, Korea Times reported that Bae's production company scrapped this project [17].
}

by the Korean Wave phenomenon led many people to further set up independent productions, of which number steeply increased from 416 in 2004 to more than 850 in late 2007. Once the production contract is made, the network pays the production cost to the production companies in advance. However, production companies usually spend more in actual drama production processes. It is because some talent management companies which own the precious stars pressure production companies to pay more after contracts are made with the network, or to include their in-house actors in the production.

There is another practice in the Korean television industry which further interferes with the prosperity of indies. It is that they have to relinquish the copyright of a drama to the networks after a drama series is signed off. If the drama is exported in Asia, $40 \%$ of foreign sales' profits goes to the production company for 3 years; the networks take the whole pie of profits resulting from sales in non-Asian regions. This unfair practice began in the early stage of the "compulsory television programming outsourcing system." Because most independent production companies were small-sized and illequipped in terms of manpower, production facilities and financial conditions, the networks provided the whole gamut of manpower--planning, writing, and directing--and production facilities to the indies in return for the copyright on programming. This practice continues till now although some indies are well-equipped to perform at every phase of television drama production. Without owning the copyright on programs, the indies cannot make profits from spin-off products such as DVD sales. As such, many independent productions, including those credited with famous Korean dramas, are reported in danger of bankruptcy.

\section{DISCUSSION}

Today, activists and scholars who are concerned with the media and communication seem to have changed their major target of criticism from the U.S. media imperialism to commercial media's corporate expansionism [11]. Policies of commercialization and liberalization have transformed the media landscape in Korea. The plurality of media companies provided more choices to audiences. Through fierce competition for audience shares, the Korean television networks acquired export capacity. Clearly, commercial competition generated incentives for self-improvement.

However, it seems that stars and industry people alike have since become too intoxicated with the Korean Wave achievement to churn out decent-priced, quality products--their original charm. Nevertheless, the Korean Wave phenomenon has deluded Korean television industry into thinking that such a foreign fandom would someday turn into economic gains. All these fandom phenomena, however, haven't turned into decent profits as the television industry expected. There are many signs that glory days of the Korean drama may pass over sooner or later. The audiences are gradually searching for other sources of entertainment than simply watching television dramas. The context of such a crisis is being aggravated by the global economic recession. Short on cash flow, Korean 
television networks are phasing out dramas earlier than originally planned, and replacing them with cost-effective variety and comedy shows. As of late 2008, the average production cost of variety shows was 28 million won per episode, while that of drama was somewhere between 100 million won and 150 million won per episode [18].

In the current situation, only some stars are flourishing to the ruin of the whole system. Without developing future-generation actors and good stories, the Korean television drama industry only relied on the so-called "Hallyu stars," most of whom including Lee Young Ae, Bae Yong Joon, Jang Dong-gun, and Lee Byung-hun are approaching their 40s. In addition, some fans have begun to find Korean dramas' revolving around similar plots such as love triangles and twist endings irksome. What is most important is that the proper function of drama which is to comfort and entertain the ordinary audiences - by presenting their social relations, agony, despair, joy and victory--should not be destroyed by the commercialism.

Policymakers, industry people, stars and fans together have to rack their brains to find solutions to the current problems and prepare for the post-Korean Wave Age.

\section{REFERENCES}

[1] H. Schiller, "Decolonization of information: Efforts toward a new international order." Latin American Perspectives, vol.5, no.1, 1978, pp. 35-48.

[2] K. Nordenstreng, The Mass Media Declaration of UNESCO, Ablex, Norwood, 1984.

[3] New York Times, "The media and the goats," 1978 (November 27).

[4] R. McChesney, Rich Media, Poor Democracy: Communication Politics in Dubious Times, University of Illinois Press, Chicago, 1999.

[5] J. Straubhaar, "National Producers and Global TV Genres: Glocalization, Localization or De-Localization," Paper presented at IAMCR conference, Porto Alegre, Brazil, 2005.

[6] J.O. Boyd-Barrett, and S. Xie, "Al-Jazeera, Phoenix Satellite Television and the Return of the State: Case studies in market liberalization, public sphere and media imperialism" International Journal of Communication, vol. 2, 2008, pp. 206-222.

[7] Doobo Shim, "Hybridity and the Rise of Korean Popular Culture in Asia," Media, Culture \& Society, vol. 28, no.1, 2006, pp. 25-44.

[8] S-y. Chin, "Cultural industry development," http://www.nownews.com/2008/07/24/91-2309741.htm retrieved 9 August, 2009.

[9] K. Choo, "To be or not to be Cool Japan?: Japanese anime industry and international collaboration," Paper presented at Workshop on Popular Culture Co-productions and Collaborations in East and Southeast Asia, December 1011, Center for Southeast Asian Studies, Kyoto University, 2008.

[10] N. Garnham, Capitalism and Communication, Sage, London, 1990.

[11] E. Herman \& R. McChesney, The Global Media, Cassell,
London, 1997.

[12] R. Williams, Culture and Society: 1780-1950, Columbia University Press, New York, 1983.

[13] I. Jarvie, Hollywood's overseas campaign, Cambridge University Press, Cambridge, UK, 1992.

[14] R. Tempest, "Euro-TV turns in to Hollywood," Los Angeles Times, 1991 (July 11), pp. A-1.

[15] S-m. Ki, and H-t. Lee, "Wigi-eui Drama Gonghwaguk," Joong-Ang Ilbo, 2008 (Nov. 8), pp. 1.

[16] J-h. Yoo, "Sin-eui Mulbangul," Hanguk Gyeongje, 2008 (Sep. 16), pp. A36.

[17] Korea Times, "Bae's 'God's Waterdrop' Project Turns Sour," http://www.koreatimes.co.kr/www/news/special/2010/01/1 78 58485.html, retrieved 18 Jan. 2010

[18] S-m. Ki, and H-t. Lee, "Drama, churyeonryo ddemyeon namneun ge eopda," Joong-Ang Ilbo, 2008 (Nov. 8), pp. 21.

[19] H-j. Song, Hye-jin, "Bangsong 3sa drama jejakbi," Chosun Ilbo, 2008 (Jun. 27), pp. A25.

[20] S-m. Ki, "Munhwa Note," Joong-Ang Ilbo, 2008 (25 Nov.), pp. 25.

[21] S-m. Lee, "Manmulsang," Chosun Ilbo, 2008 (Dec. 8).

[22] Doobo Shim, "The growth of Korean cultural industries and the Korean wave," In Chua Beng Huat \& Koichi Iwabuchi (Eds.), East Asian Pop Culture, Hong Kong University Press, Hong Kong, 2008, pp. 15-31.

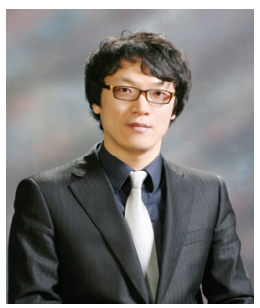

\section{Doobo SHIM}

$\mathrm{He}$ is associate professor at the Department of Media and Communications, Sungshin Women's University, where he teaches, and does research on, media studies within critical, cultural and historical perspectives. He finished his Ph.D. thesis at the University of Wisconsin-Madison in 2000 before assuming assistant professor position at the National University of Singapore. Currently, he is working on dynamics of Asian media industries and international communication theories. 